\title{
Tensile strength comparison of composite specimens printed in FDM technology with specimens printed from PLA
}

\author{
Porównanie wytrzymałości na rozciąganie próbek kompozytowych \\ wydrukowanych w technologii FDM z próbkami wydrukowanymi z PLA
}

\author{
WOJCIECH KIŃSKI \\ PAWEK PIETKIEWICZ \\ KRZYSZTOF NALEPA \\ WOJCIECH MIĄSKOWSKI *
}

DOI: https://doi.org/10.17814/mechanik.2017.7.90

\begin{abstract}
Presented is the breaking strength test of specimens printed in FDM (fused deposition modeling) technology with different filling density, of PLA and PET materials: combined with each other. The aim of the study is to investigate the influence of technological parameters on the strength parameters of the produced object and to compare specimens printed of two materials simultaneously with those made of a single material.

KEYWORDS: 3D printer, strength test, FDM, combining materials
\end{abstract}

Plastic parts are usually manufactured by injecting plastic into the mold. Increasingly, small-scale or prototype production is based primarily on the production of components using 3D printers. The most common technology is FDM (fused deposition modeling), which consists in building a model by applying a melt-layer plastic layer, bonding previously applied layers. Plastic usually in the form of a wire wound on a reel - is taken into the header where it is heated to the melting point and extruded through a die [1, 2].

The 3D printers allow the production of models with different materials: plastic and composites. When selecting the raw material the user is guided by the material parameters. However, in incremental technologies (also FDM), the direction of application of the material is important, which determines the strength properties of the print in different planes. Model parameters, temperature and print speed are also influenced by the model's strength.

\section{Comparative tests of tensile strength}

The strength tests were performed in the Materials Strength Laboratory at the Department of Mechanics and Machine Building of the University of Warmia and Mazury in Olsztyn. Tensile testing methods for plastics are described in PN-EN ISO 527:1998 - Plastics. Determination of mechanical properties at static tension.

\footnotetext{
* Mgr inż. Wojciech Kiński (wojciech.kinski@uwm.edu.pl), dr inż. Paweł Pietkiewicz (papiet@uwm.edu.pl), dr inż. Krzysztof Nalepa (nalepka@uwm.edu.pl), dr inż. Wojciech Miąskowski (wojmek@uwm.edu.pl) _ Wydział Nauk Technicznych Uniwersytetu Warmińsko-Mazurskiego
}

The 3D model has been modeled in SolidWorks. To read the printer is required for entry in the STL format. STL model is built from triangles, thus mapping arches and circular elements is somewhat simplified.

Fig. 1 shows a sample with its characteristic dimensions, which are summarized in Table I.

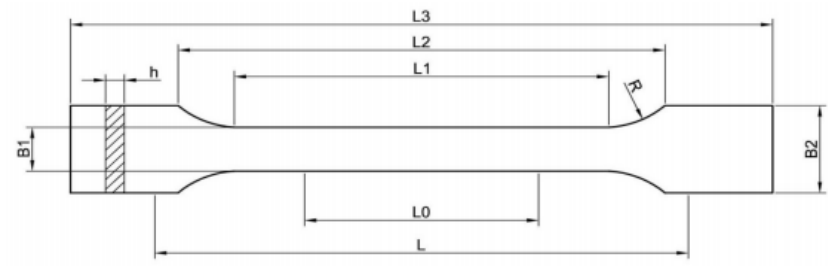

Fig. 1. Sample for strength test

TABLE I. Sample dimensions

\begin{tabular}{|l|c|}
\hline \multicolumn{1}{|c|}{ Dimensions of the sample } & $\begin{array}{c}\text { Dimensions, } \\
\mathrm{mm}\end{array}$ \\
\hline$L 3-$ total length & 150 \\
\hline $\begin{array}{l}L 1-\text { ength of the part between } \\
\text { lines }\end{array}$ & 40 \\
\hline$R-$ radius & 60 \\
\hline $\begin{array}{l}L 2-\text { the distance between the } \\
\text { wide parallel elements }\end{array}$ & 106 \\
\hline$B 2-$ width at the ends & 20 \\
\hline$B 1-$ width of the narrow part & 10 \\
\hline$H-$ recommended thickness & 4 \\
\hline$L O-$ measuring length & 50 \\
\hline$L-$ initial distance between handles & 115 \\
\hline
\end{tabular}

For strength tests, samples were made from:

- PLA material,

- PET material,

- combination of PLA and PET materials, the sample core was made of PLA material and the model wall made of PET material,

- combination of PLA and PET materials, the sample core made of PET material, and the model wall - made of PLA material. 
Combining two materials was possible due to the innovative professional 3D printer provided with two print heads. Table II contains values of the print samples.

\section{TABLE II. Printing parameters}

\begin{tabular}{|l|c|}
\hline \multicolumn{1}{|c|}{ Name } & Value \\
\hline Height of the layer, $\mathrm{mm}$ & 0,2 \\
\hline Printing speed, $\mathrm{mm} / \mathrm{s}$ & 70 \\
\hline The wall thickness of the model, $\mathrm{mm}$ & 0,8 \\
\hline Air flow cooling the print, $\%$ & 100 \\
\hline Table temperature, ${ }^{\circ} \mathrm{C}$ & 65 \\
\hline Head temperature $\mathrm{PLA},{ }^{\circ} \mathrm{C}$ & 200 \\
\hline Head temperature $\mathrm{PET},{ }^{\circ} \mathrm{C}$ & 235 \\
\hline Diameter of head nozzle, $\mathrm{mm}$ & 0,4 \\
\hline
\end{tabular}

Table III shows the results of strength tests of samples made from one material.

TABLE III. Results of strength tests of samples made from one material

\begin{tabular}{|l|c|c|}
\hline \multirow{2}{*}{} & \multicolumn{2}{|c|}{$\begin{array}{c}\text { Average breaking } \\
\text { strength, kN }\end{array}$} \\
\cline { 2 - 3 } & PLA & PET \\
\hline $\begin{array}{l}\text { Only crust (empty model in the } \\
\text { middle) }\end{array}$ & 0,45 & 0,14 \\
\hline Only filling without crust & 2,06 & 1,12 \\
\hline Stroke with fill & 2,15 & 1,36 \\
\hline
\end{tabular}

Studies, the results of which are listed in Table III, were made for three variants of the samples. The samples with the lowest tensile strength consisted only of the outer wall and were not filled. Higher tear strength values were obtained for samples without the outer layer. The highest values of tensile strength was observed with samples consisting of the outer layer and the fill. The burst force of the PET material is close to the sum of the core bursting forces and the outer layer without filling. The greater the divergence from this rule was observed in the study sample with PLA material.

Table IV shows the results of the tensile strength test of samples made from the combination of PLA and PET materials, the outer wall made of PLA material and filled with PET material. The density of the samples was increased from 0 to $100 \%$ in steps of $10 \%$. Filling the sample took the form of a grid at an angle of $45^{\circ}$.

The results showed a tendency to increase the value of tensile strength sample with an increasing degree of filling of the cross sectional area of the material, wherein both the filling of $20 \%$, and $60 \%$ to $70 \%$ of the sample had lower tensile strength than the samples were packed respectively $10 \%$ and $30 \%$, and $50 \%$ and $80 \%$.
TABLE IV. Summary of average bursting forces of PLA wall and PET core

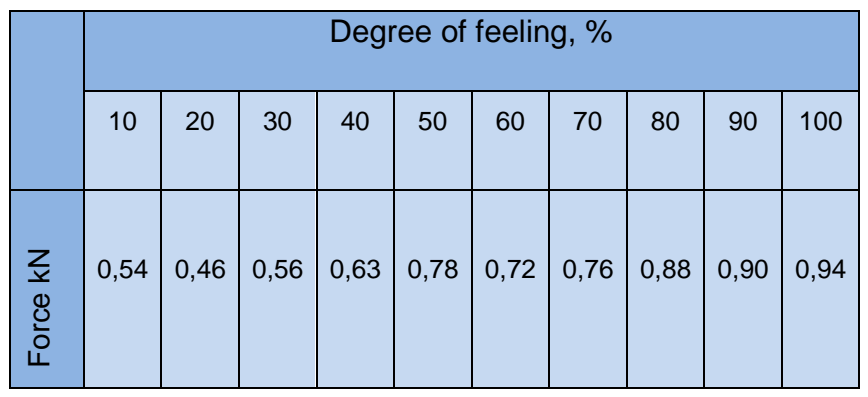

While the tendency to increase the bursting force along with the degree of filling of the sample core with the material was as expected, the bursting force for the sample filled with $100 \%$ material did not correspond to the values given in Table. III for samples made of one material. The value of the sample burst strength of the combined materials was significantly lower than that of the sample consisting of the PET core itself and the full PET sample.

An additional comparison was made of the value of sample burst forces in all variants, assuming that the cores are filled with $100 \%$ material. The results of the comparison are given in Table $\mathrm{V}$.

TABLE V. Comparison of sample burst strength with $100 \%$ core

\begin{tabular}{|c|c|c|}
\hline $\begin{array}{c}\text { Wall } \\
\text { material }\end{array}$ & $\begin{array}{c}\text { Core } \\
\text { material }\end{array}$ & $\begin{array}{c}\text { Value of bursting } \\
\text { strength, } \mathrm{kN}\end{array}$ \\
\hline PLA & PLA & 2,15 \\
\hline PET & PET & 1,36 \\
\hline PET & PLA & 1,38 \\
\hline PLA & PET & 0,94 \\
\hline
\end{tabular}

Fig. 2 shows the interpretation of the results from Tables III and V. A comparison of the results shows that the use of a combination of materials significantly lowers the tensile strength of the sample when the stretching. In the case of samples made of PLA material, the use of an outer wall of PET material weakens the tensile strength by nearly $36 \%$, and for PET-made samples, the use of PLA outer wall reduces the sample tensile strength by almost 31\%.

The observed reduction in tensile strength using a combination of materials has forced the research team to analyze the possible causes of such a phenomenon. It seems that the key aspect is the course of deformation of the samples before they burst during stretching. Fig. 3a shows a photograph of the sample material made of PLA formed by a break in a tensile test. To the right of it, there is a characteristic narrowing, which is formed before the rupture of the sample. Fig. 3b shows an analogous photograph of a sample made from a combination of materials, the sample core being made of PLA, and a PET wall. The sample was deformed consisting in the 
occurrence of necking. Visible tearing of the structure without a visible change in the transverse dimension of the sample. A similar phenomenon occurred in the case of a sample made of both materials, with a PET core and a PLA wall (Fig. 3c).

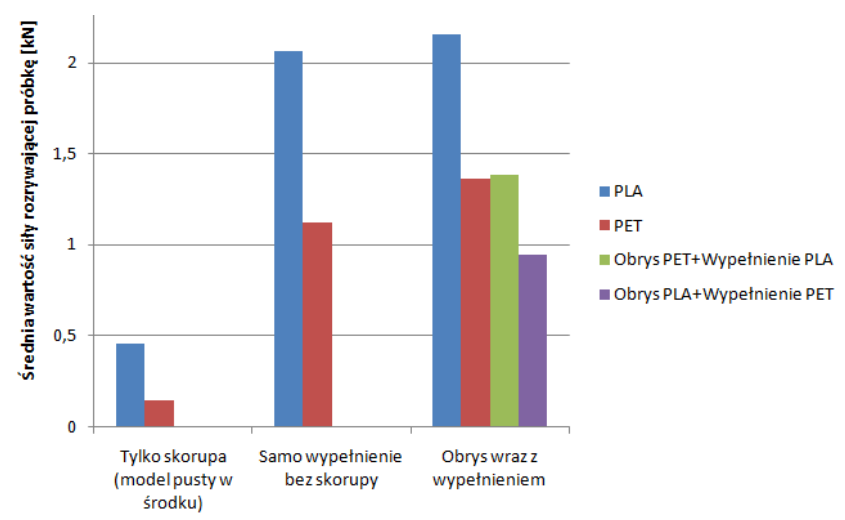

Fig. 2. Comparison of average bursting force for each variant of the samples

a)

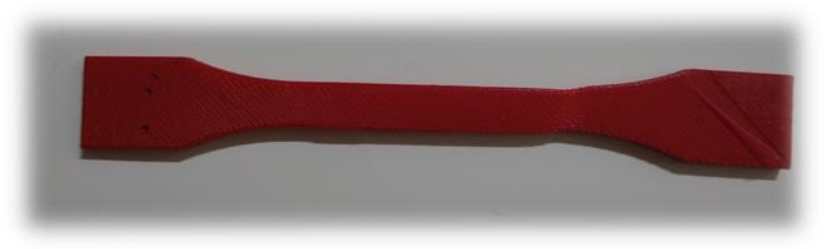

b)

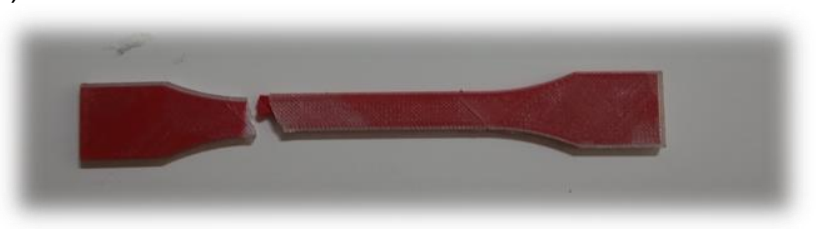

c)

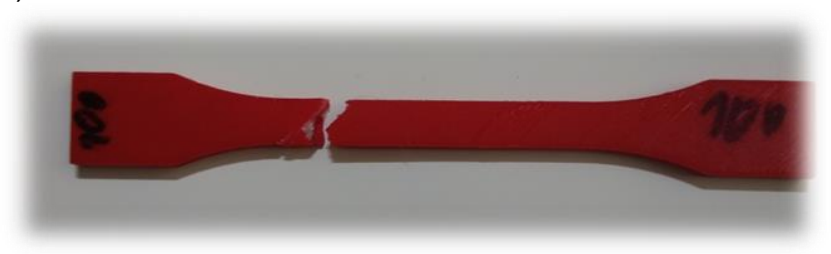

Fig. 3. Samples: a) with PLA with characteristic narrowing; b) composite - PET wall, PLA core; c) composite - PLA wall, PET core

Phenomenon of the characteristic sample necking absence during stretching leads to a conclusion that samples made of the composite differ significantly from samples made of a single material.

\section{Conclusions}

The strength tests allowed us to compare the values of tensile strengths subjected to stretching of the sample by FDM 3D printing with different material filling configurations. Analysis of the results allows us to formulate several conclusions:

- Despite the strong anisotropic structure of the material, thanks to its extensive software and innovative equipment, the durability of products obtained through 3D printing can be significantly influenced. By changing the filling structure of the cross-section of the printouts. - Despite the anisotropic structure of 3D-printed models from a single material, stretch marks exhibit characteristic isotropic deformations of the sample in the form of a narrowing.

- Combining materials in the printed samples alters their properties considerably enough so that no stretching occurs during the stretching tests, such as in samples made of one material.

- Joining of materials greatly reduces the value of the composite materials' burst strengths as compared to the values of the breaking forces of the materials from which these composites are deposited. The use of composites in 3D printing technology does not guarantee an increase in the durability of FDM printouts.

The results of strength tests indicate the need for the continuation of this kind of research in the context of changes in the parameters of each print materials included in the composite.

The work was carried out within the framework of the project "Functional models and studies of the construction of a quasi-autonomous lighting or signaling point" (Decision of the Minister of Science and Higher Education No. 5119/B/T02/2011/40 of 4 February 2011).

\section{REFERENCES}

1. http://reprap.org/ (dostęp: 21.02.2017 r.).

2. Choi J., Medina F., Kim Ch., Espalin D., Rodriguez D., Stucker B., Wicker

R. "Development of a mobile fused deposition modeling system with enhanced manufacturing flexibility". Journal of Materials Processing Technology. 211 (2011): pages 424-432.

3. http://www.centrumdruku3d.pl/ (dostęp: 21.02.2017 r.).

4. Miazio $Ł$. „Badanie wytrzymałości na rozciąganie próbek wydrukowanych w technologii FDM z różną gęstością wypełnienia”. Mechanik. 7 (2015): pages 533-538. 